\title{
Occupational Health during the Second World War: Hope Deferred or Hope Abandoned?
}

\author{
H A WALDRON*
}

When E R A Merewether, the Senior Medical Inspector of Factories, reviewed the health of the workforce during the Second World War, he wrote that, "it was a matter of surprise and relief that the general standard of Industrial Health has kept at such a high level". 1 At the outbreak of war the health of the workforce had been expected to decline although experience in the First World War had shown that the health of the workforce had been improved by attention to such things as comfort and well-being through the provision of first aid, canteens and cloakrooms, and some form of occupational health service. $^{2}$ J C Bridge, writing of industrial medicine between 1914 and 1918 noted that it was then realized for the first time that fatigue, under-nourishment and other conditions both within and outside work were as important causes of ill health as the toxicity of the materials which were handled. He continued by saying that

the [first world] war period had . . a very great influence on industrial medicine. It showed quite emphatically that the health of the worker was a factor of great economic value and that a worker maintained in good health was of prime importance. We find, therefore, following the war a number of medical men appointed as whole or part-time Works Doctors. ${ }^{3}$

The lesson of the First World War may not have been as durable as Bridge had supposed, for, in 1919, the Lancet compared the situation of industrial medicine in Britain unfavourably with that in the United States. "The profession", wrote its leader writer, “. . .

*H A Waldron, MD, Department of Occupational Health, St Mary's Hospital, London, W2 1NY.

\footnotetext{
${ }^{1}$ E R A Merewether, 'Industrial health', in Annual report of the Chief Inspector of Factories for the year 1945, London, HMSO, 1946, pp. 58-85. Merewether was appointed a medical inspector in 1927 and became Senior Medical Inspector in 1943; he died in 1970, see, Lancet, 1970, i: 477-8.

2 Winter has produced some evidence that the mortality of some groups of workers, especially manual workers, actually improved during the First World War, brought about fundamentally by improvements in the state of nutrition, and in this, the provision of industrial canteens was significant. J E Winter, The great war and the British people, London, Macmillan, 1985. The health of some groups of workers, however, was certainly adversely affected; see, for example, A Ineson and D Thom, 'T.N.T. poisoning and the employment of women in the First World War', in P Weindling (ed.), The social history of occupational medicine, London,
}

Croom Helm, 1985, pp. 89-107. The health of the general population during the Second World War has been examined by Jones. Civilian health deteriorated in 1940 and 1941 but improved from 1942 onwards, although inequalities in the standards of health remained. There was a decrease in many causes of death, although tuberculosis was a notable exception; at least some of the improvement in health was due to improvements in nutrition. H Jones, Health and society in twentieth century Britain, London, Longman, 1994.

3 J C Bridge, 'Health', in Annual report of the Chief Inspector of Factories and Workshops for the year 1932, London, HMSO, 1933, pp. 41-57. The year in which the report was published (1933) marked the anniversary of the appointment of the first four Government Inspectors of Factories under the provision of the Factory Act of 1833 and it included a review of the work of the inspectors during the period. Bridge himself joined the medical inspectorate in 1914, became Senior Medical Inspector in 1927 and retired in 1942. 


\section{H A Waldron}

is far from awake to its responsibilities for paying to the industrially employed that close attention necessary to increase our national productivity . ..". Nevertheless, industrial medicine was expected to play an important part during the Second World War, and so it did; the clear benefits which the work force-and hence the economy-could derive from it generated an enthusiasm for the subject which has not been equalled since, and it was anticipated that the specialty would continue to develop after the war and continue to make a great contribution to the health of the nation. This paper examines this upsurge in interest in industrial medicine and some of the consequences.

\section{Industrial Medicine in the Inter-War Period}

Although Bridge noted in his review that some firms appointed whole or part-time medical officers after the First World War, it is difficult to get any information about how many actually did so and which they were. ${ }^{5}$ By 1935 , however, industrial medical officers were sufficient in number to form an Association, for unpretentious talk between friends, as one senior medical inspector described it. ${ }^{6}$ The twenty founder members held their first meeting on 27 September 1935 at the London School of Hygiene; the first chairman was Dr N Howard Mummery of J Lyons \& Co, and the honorary secretary was Dr Donald Stewart of ICL, Birmingham. ${ }^{7}$

The number of medical officers between the wars remained small, however, and when the war began there were only 50 full-time medical officers in British industry and 250 part-timers, many of whom were women. ${ }^{8}$ Most work was undertaken by Certifying Factory Surgeons. These officials were first appointed under the terms of the Factories Act of 1839 which gave factory inspectors the power to appoint persons practising surgery or medicine to be certifying surgeons for the purpose of obtaining the certificate of age which the Act required. They were also required to report and investigate industrial accidents, and later to examine all young persons under the age of sixteen starting to work in any factory to ensure their fitness, and to examine young men between the ages of sixteen and eighteen who were required to take on shift work. As codes and regulations for hazardous trades-in particular, working with lead-were promulgated, the certifying surgeons found themselves undertaking the periodic medical examinations which these codes and regulations required.

\footnotetext{
4 'Industrial medicine in America and here', Lancet, 1919, ii: 1199-200.

${ }^{5} \mathrm{R}$ E Lane states that when he started to work at the Chloride Company in 1927 there were very few doctors in industry. Pilkingtons, Boots, Lyons, and ICI are amongst those companies which he remembers as having full time medical officers around that time. 'My fifty years in industrial medicine', J. Soc. occup. Med., 1978, 28: 115-24.

$6 \mathrm{~T}$ W Lloyd Davies, 'Evolution of concepts in industrial medicine', Br. J. ind. Med., 1966, 23: 165-72. Previously, industrial medical officers had formed an advisory committee within the Industrial Welfare Society, a voluntary organization directed by Robert Hyde. Matters of general interest were discussed and papers read within this forum but as
}

the numbers grew, the need for a separate organization was felt and the independent Association was formed, "much to Robert Hyde's chagrin" (Lane, op. cit., note 5 above, p. 116).

7 A report of the proceedings of this first meeting can be found in the Br. med. J., 1935, ii: 645-6. The report contained a number of inaccuracies about the Association which were subsequently corrected by Mummery (Br. med. J., 1935, ii: 879). The Association subsequently became the Society of Occupational Medicine.

${ }^{8} \mathrm{R}$ Cooter, Surgery and society in peace and war: orthopaedics and the organization of modern medicine, 1880-1948, London, Macmillan, 1993, p. 144. 


\section{Occupational Health during the Second World War}

The Factories Act of 1937 permitted the Secretary of State to direct the certifying surgeons to make a special enquiry or examination of certain categories of people at work and to investigate any cases of notifiable disease which had been reported. In addition, under Section 60 of the 1937 Act, the Secretary of State was given powers to make special regulations with respect to health and safety in factories where dangerous trades were carried out. Wherever there was a risk of an occupational disease occurring which could be recognized early in its course by medical examination, the Secretary of State could require that employees engaged in the process involved underwent periodic checks. Doctors acting under Section 60 were referred to as "Appointed Surgeons" and in practice most of these were certifying (or examining) surgeons although works medical officers were also permitted to act as appointed surgeons. ${ }^{9}$

For the purposes of appointing certifying surgeons, the country was divided up into about 1,700 districts, each with its own certifying surgeon appointed by the factory inspector. ${ }^{10}$ It is evident that with only about a dozen medical inspectors of factories and perhaps only three or four times that number of full-time medical officers in industry, the great bulk of the work required under regulations was carried out by the certifying surgeons. In 1937, for example, they performed between them nearly three-quarters of a million medical examinations, details of which were reported in the Annual report of the Chief Inspector of Factories; they continued to work at a similar rate throughout the war (Table $\left.1^{11}\right) .^{12}$

The certifying surgeons also provided certificates to workers whom they considered to be suffering from prescribed industrial diseases which attracted some compensation, and many thousands of these certificates were issued each year. ${ }^{13}$ Appeals against the decision of the certifying surgeon were referred to medical referees, doctors appointed by the Home Office. They were consultants in private practice and their experience of industrial conditions and of industrial diseases would necessarily have been small.

\section{The Medical Inspectorate}

The other major players in industrial medicine between the wars were the medical inspectors of factories, the first of whom was appointed in $1898 .{ }^{14}$ It was surprising that

\footnotetext{
9 There is a good contemporary account of the work of the Examining Surgeon in H E Collier, Outlines of industrial medical practice, London, Edward Arnold, 1940, pp. 401-7.

10 The certifying surgeons formed an association (the Association of Certifying Medical Officers) in 1868, but this was short-lived and broke up in 1878 or 1879 . It was succeeded by the Association of Certifying Factory Surgeons which was founded in Manchester in 1889. For further details of the history of the certifying surgeons see S Huzzard, 'The role of the certifying factory surgeon in the state regulation of child labour and industrial health, 1833-1973', MA thesis, University of Manchester, 1976.

${ }^{11}$ In this, and other tables, I have included some extra years before and after the war period for comparison.
}

12 The Examining Surgeons became known as Appointed Factory Doctors in 1948 and their remit was examined by a Sub-Committee of the Industrial Health Advisory Committee in 1966, following which their duties were considerably changed.

${ }^{13}$ For example, A F Young calculated that between 1933 and 1935 an average of 13,000 certificates per annum was issued by certifying surgeons, see Industrial injuries insurance: an examination of British policy, London, Routledge and Kegan Paul, 1964, p. 31.

14 The work of the non-medical inspectors in the inter-war years is discussed by Helen Jones; she argues that, for a number of reasons, their work was less effective than it might have been. See, 'An inspector calls: health and safety at work in inter-war Britain', in Weindling, op. cit., note 2 above, pp. 223-39. 


\section{H A Waldron}

Table 1

Number of examinations carried out by certifying (examining) surgeons, 1937-1946

$\begin{array}{cccc}\text { Year } & \begin{array}{c}\text { Children aged } \\ 14-16\end{array} & \text { Boys aged over } 16^{\mathbf{a}} & \begin{array}{l}\text { In connectio } \\ \text { dangerous }\end{array} \\ 1937 & 384,870 & & 351,693 \\ 1938 & 363,366 & 2,146 & 372,974 \\ 1939 & 410,141 & 3,766 & 377,969 \\ 1940 & 388,303 & 10,322 & 391,622 \\ 1941 & 329,861 & 12,572 & 419,701 \\ 1942 & 273,298 & 10,600 & 345,057 \\ 1943 & 249,578 & 9,660 & 378,334 \\ 1944 & 234,612 & 8,691 & 473,319 \\ 1945 & 228,073 & 8,102 & 344,958 \\ 1946 & 262,231 & 7,020 & 286,799\end{array}$

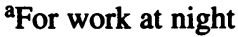

bLead workers were the most significant in this group numerically

Data from Annual reports of Chief Inspector of Factories.

after the passage of the first factory act it took so long for medical men to be considered necessary in the factory inspectorate. ${ }^{15}$ Two years before the first factory act was passed, Charles Thackrah had published his book The effect of the principal arts, trades and professions; and of civil states and habits of living on health on longevity, with suggestions for the removal of many of the agents which produce disease and shorten the duration of life. Thackrah knew from his own clinical experience in Leeds that, “. . . our employments are in considerable degree injurious to health . . ." but considered that there were many who

believe, or profess to believe, that the evils cannot be counter-acted, and urge that an investigation of such evils can produce only pain and discontent. From a reference to fact and observations I reply, that in many of our occupations, the injurious agents might be immediately removed or diminished. Evils are suffered to exist, even when the means of correction are known and easily applied. ${ }^{16}$

Such outspoken views would not have endeared Thackrah to the industrialists of the day and we may speculate whether their opposition hindered the appointment of medically qualified men into the factory inspectorate; the fact that Thackrah died in 1832 at the early age of thirty-seven could not have done much to hasten such appointments.

The first medical inspector, in 1898, was Thomas Legge ${ }^{17}$ who continued in office until 1926 when he resigned in protest at the failure of the government to ratify the Geneva

\footnotetext{
15 There had, in fact been two medical men in the inspectorate prior to the appointment of the first medical inspector. The first was Robert Baker who was appointed sub-inspector of factories in Leeds in 1834 and became one of the two chief inspectors in 1858. See W R Lee, 'Robert Baker: the first doctor in the Factory Department. Part 1. 1803-1858', Br. J. ind. Med., 1964, 21: 85-93; 'Part II. 1858 onwards', ibid, 1964, 21: 167-79. The second was Sir Arthur Whitelegge who had been Medical Officer of Health
}

for Nottingham until 1889 when he became Medical Officer for the West Riding of Yorkshire; he was appointed Chief Inspector of Factories in 1896, in which post he remained until 1917. He died in 1933.

16 Published by Longmans, London, 1831, p. 17.

17 Thomas Legge was appointed in the first instance to deal with the many cases of industrial disease notified by the certifying factory surgeons and other medical practitioners, in particular lead and phosphorus poisoning. Legge helped to draft the ILO 
White Lead Convention. The medical inspectorate was always small and during the Second World War it numbered between eleven and fourteen. Despite its small size, however, it included some of the most important figures in occupational medicine, who made many notable contributions to the specialty. Between the wars there were never more than eight medical inspectors in post, always including one woman. The first female medical inspector, Dr Eileen Hewitt, was appointed in 1921 but she was forced to resign in 1923 when she married, such were the rules of the Civil Service at the time. Her successor, Dr Sybil Overton (appointed in 1924) managed to circumvent the rules and was allowed to remain in office when she married in $1931 .^{18}$

\section{The Industrial Fatigue Research Board}

Because of the perceived success of the Committee on the Health of Munitions Workers during the First World War, the Secretary of State for Home Affairs invited the Department of Scientific and Industrial Research and the Medical Research Committee (MRC) to appoint a committee to investigate industrial fatigue and in particular, its effects on production. ${ }^{19}$ The new body was established in 1918 and was known as the Industrial Fatigue Research Board; its first report, by H M Vernon, was published in 1919 and entitled The influence of hours of work and of ventilation on output in tinplate manufacture. ${ }^{20}$ In 1929 the scope of the Board was enlarged and it came wholly under the auspices of the MRC. Whereas, before, the terms of reference related solely to the production of fatigue by hours of work and other conditions of employment, they now encompassed the preservation of health generally. The Board was given a new name and was thereafter known as the Industrial Health Research Board. By 1939, the Board had produced eighty-four reports and the results of some of these were summarized in a series of emergency reports published during the war in which results from earlier studies were presented in a form in which it was hoped they might be applied for the benefit of the war effort. ${ }^{21}$ The Board was reconstituted for the third time in 1942 when its terms of reference were again broadened to include psychological effects for the first time, and, to a much greater extent than before, the prevention or amelioration of illness caused by exposure to particular hazards at work. ${ }^{22}$

White Lead Convention in 1921 which prohibited the use of lead-based paints inside houses. When the government refused to ratify the convention Legge resigned his post and subsequently became medical adviser to the TUC. R Murray, 'Sir Thomas Morison Legge', J. Soc. occup. Med., 1985, Jubilee Issue, pp. 23-8.

18 There has been no satisfactory history of the Medical Inspectorate and its work. Some brief details, with engaging vignettes of a number of the more eminent inspectors are to be found in Miles Kipling's little book, A brief history of HM Medical Inspectorate (London, Health \& Safety Executive) published in 1979, the year after his death.

19 The Health of Munitions Workers Committee was set up in 1915 to advise the Minister of Munitions (Lloyd George) on questions affecting "industrial fatigue, hours of labour and other matters affecting the personal health and efficiency" of munitions workers. (A J McIver, 'Employers, the government, and industrial fatigue in Britain, 1890-1918', Br. J. ind. Med., 1987, 44: 724-32.)

20 The Research Board was first chaired by Charles Sherrington and included Thomas Legge; the secretary was D R Wilson, one of the factory inspectors of the time. Its terms of reference are to be found in its first and subsequent reports.

${ }^{21}$ The first of these, published in 1940, was entitled Industrial health in war. A summary of research findings capable of immediate application in furtherance of the national effort, London, HMSO.

22 For further details, see the preface to the third emergency report, The personal factor in accidents, London, HMSO, 1942, pp. 3-4. The history of the Board has been recorded by R S F Schilling who became its secretary in 1942: 'Industrial health research: the work of the Industrial Health Research Board, 1918-44', Br. J. ind. Med., 1944, 1: 145-52. 


\section{H A Waldron}

\section{The Industrial Health Education Society}

The Industrial Health Education Society (IHES) began in 1922 in Scotland as the Industrial Health Education Council with the aim of providing information to workers on occupational diseases and to help them deal with the specific diseases to which their occupations made them liable. The Society was reconstituted as the IHES in 1924 and moved its offices to London in 1927. Lectures were given throughout the country and leaflets were produced and a number of medical men were active in its affairs, especially some of the medical officers of health. The Society did not succeed in involving employers to any extent in its work and its success in preventing occupational disease has not been assessed; it ceased to function in 1940 although not formally wound up until $1944 .^{23}$

\section{The Effect of War on the Health of the Workers}

Conditions of work during the war were arduous; a large and often inexperienced workforce spent long hours in factories that were often poorly lit, badly heated and badly maintained. The requirement for complete blackout meant that ventilation systems were often inadequate and this resulted in greater exposure than normal to some toxic substances. In addition, the exigencies of war required that some substances banned in peacetime had to be used again; for example, benzene was once more introduced into the munitions industry. ${ }^{24}$

The poor conditions and the fatigue suffered by the workers inevitably resulted in an increase in morbidity and mortality, although in both his 1940 and 1941 reports, Bridge wrote that he could find no evidence that the general health of the workforce had been adversely affected by the demands of war. ${ }^{25}$ Nevertheless, there is no question that the number of cases of specific industrial diseases increased substantially, particularly in the munitions industry. Those associated with handling TNT increased considerably once the war effort was in full swing. This applied to cases of aniline poisoning also, which became especially numerous in 1941 and 1942, as did cases of toxic jaundice and toxic anaemia, including some fatalities (see Table 2). Conversely, the number of cases of lead poisoning actually fell during the war and the total of 59 recorded in 1941 was the lowest since notification of the disease began in 1899 . There was a very considerable rise in the number of gassings, however, mainly due to poisoning with carbon monoxide or nitrous fumes (Table 3a), and not only in the absolute numbers but also, significantly, in their rate (Table 3b).

\footnotetext{
${ }^{23}$ For the history of the IHES, its aims and achievements see, A Watterson, 'Health education in the UK workplace: looking backwards and going forwards? The IHES at work 1922-1940', Br. J. ind. Med., 1990, 47: 366-71.

24 The use of benzene had been strongly discouraged by the Factory Inspectorate and safer solvents such as toluene had replaced it. Sporadic cases of benzene poisoning still occurred, however, often because benzene was inadvertently-or
}

sometimes deliberately - used in processes such as paint-spraying. The single case of benzene poisoning notified in 1937 (and shown in Table 2) was-most unusually-not referred to by Bridge in his report for that year and so the cause is unknown.

$25 \mathrm{~J} \mathrm{C}$ Bridge, in Annual report of the Chief Inspector of Factories for the year 1940, London, HMSO, 1941, p. 21; idem, Annual report . . . 1941, London, HMSO, 1942, p. 19. 


\section{Occupational Health during the Second World War}

Table 2

Number of some industrial diseases notified to the Factory Inspectorate, 1937-1946

\begin{tabular}{|c|c|c|c|c|c|c|c|c|c|c|}
\hline & 1937 & 1938 & 1939 & 1940 & 1941 & 1942 & 1943 & 1944 & 1945 & 1946 \\
\hline $\begin{array}{l}\text { Lead } \\
\text { poisoning }\end{array}$ & 141 & 96 & 109 & 108 & 59 & 72 & 46 & 41 & 45 & 47 \\
\hline Fatalities & 19 & 19 & 6 & 6 & 5 & 3 & 5 & 2 & 2 & 8 \\
\hline $\begin{array}{l}\text { Aniline } \\
\text { poisoning } \\
\text { Fatalities }\end{array}$ & 10 & 9 & 12 & 64 & 249 & 204 & 79 & 55 & 31 & $\begin{array}{r}19 \\
1\end{array}$ \\
\hline $\begin{array}{l}\text { Chronic } \\
\text { benzene poisoning }\end{array}$ & 1 & & 2 & 3 & 1 & 1 & 1 & 1 & 1 & 1 \\
\hline Fatalities & & & & 2 & 1 & 1 & 1 & 1 & & 1 \\
\hline Toxic jaundice & 4 & 4 & & 20 & 44 & 27 & 16 & 12 & 6 & 1 \\
\hline Fatalities & 1 & 1 & & 4 & 13 & 6 & 4 & 1 & 2 & \\
\hline Toxic anaemia $^{a}$ & & & & & & 14 & 7 & 12 & 7 & 1 \\
\hline Fatalities & & & & & & 3 & 4 & 6 & 2 & 1 \\
\hline
\end{tabular}

${ }^{\text {a}}$ First made notifiable in 1942.

Data from Annual reports of Chief Inspector of Factories.

The other major way in which industrial health was adversely affected was in the large number of accidents (Table 4). There was an absolute increase in the number of fatal and non-fatal accidents, peaking in 1942 when all those reported totalled 314,630. One must suppose that the Factory Inspectorate was not informed of all accidents and that the true number was much greater. Most occurred in industries engaged in manufacturing munitions and many occurred to women. In 1942 women were involved in 66 per cent more accidents than in 1941.

It is noticeable in Table 4 that not only did the absolute number of accidents rise during the war years, but the rate of accidents also increased, so that in 1942 roughly 1 in 23 workers was involved in an accident. This was a matter of great concern and was due to various interacting factors: women were employed in jobs in which they had no previous experience; ${ }^{26}$ the Factory Inspectorate commented on the employment of older men who perhaps lacked the quickness and manual dexterity required; rapidly increasing production schedules; poor maintenance; and inadequate supervision. ${ }^{27}$ During the last two years of the war, when it became possible to relax production schedules and lift the blackout restrictions, the accident rate fell and the number of fatal accidents was half its 1941 peak.

\footnotetext{
26 The experience of women workers during the Second World War has been examined by Summerfield. She argues that, contrary to the standard interpretation, the war did little to change the unequal position of women in society. P Summerfield, Women workers in the second world war: production and patriarchy in conflict, London, Croom Helm, 1984.
}

\footnotetext{
27 There is a comprehensive report on the Factory Inspectorate's investigations into industrial accidents in the Annual report of the Chief Inspector of Factories for the year 1942, London, HMSO, 1943, pp. 5-12.
} 


\section{H A Waldron}

Table $3 a$

Number of gassing accidents due to carbon monoxide and nitrous fumes, and total number of all gassing accidents reported to the Factory Inspectorate, 1937-1946

\begin{tabular}{|c|c|c|c|c|c|c|c|c|c|c|}
\hline & 1937 & 1938 & 1939 & 1940 & 1941 & 1942 & 1943 & 1944 & 1945 & 1946 \\
\hline Carbon monoxide & 92 & 98 & $84^{a}$ & 162 & 258 & 249 & 231 & 209 & 218 & 117 \\
\hline Number of fatalities & 13 & 14 & 5 & 20 & 24 & 11 & 17 & 21 & 18 & 11 \\
\hline Nitrous fumes & 7 & 14 & 9 & 236 & 217 & 220 & $13 \dot{5}$ & 55 & 29 & 13 \\
\hline Number of fatalities & 1 & 1 & 0 & 2 & 1 & 2 & 4 & 1 & 0 & 0 \\
\hline $\begin{array}{l}\text { Total number of } \\
\text { gassings }\end{array}$ & 196 & 190 & 184 & 585 & 782 & 776 & 695 & 450 & 427 & 243 \\
\hline $\begin{array}{l}\text { Total number of } \\
\text { fatalities }\end{array}$ & 20 & 27 & 11 & 31 & 41 & 25 & 27 & 25 & 27 & 13 \\
\hline
\end{tabular}

${ }^{\mathrm{a}} 40 \%$ of these cases occurred in the last quarter of the year.

Data from Annual reports of Chief Inspector of Factories.

Table $3 b$

Rates for all gassing accidents reported to the Factory Inspectorate, 1938-1944

Gassing accidents, rate $/ 10^{5}$ of total workforce subject to the Factories Act ${ }^{\text {a }}$ $\begin{array}{lllllll}1938 & 1939 & 1940 & 1941 & 1942 & 1943 & 1944\end{array}$

$\begin{array}{lrrrrrrr}\text { Men only } & 5.25 & 4.72 & 14.92 & 19.70 & 19.50 & 17.684 & 11.84 \\ \text { Men \& women } & 3.40 & 3.06 & 9.32 & 11.92 & 11.15 & 9.93 & 6.70\end{array}$

a Except for those working in places under Section 105-108 of the Act.

Data on the number of men and women at work obtained from Annual report of Chief Inspector of Factories for the year 1944, p. 6. The number of men in work remained more or less constant throughout the period but there was a steady increase in the number of women working from 1938 to 1943; the number fell slightly in 1944. The increase in the rate using data only for men is highly significant $(p=0.005)$; for men and women together the rate is still (just) significant, $p=0.048$.

\section{Industrial Medical Services}

To cope with the increased demand for industrial medical services, the number of full-time and part-time medical officers rose and by the end of the war there were over a thousand doctors engaged on some basis or other in industry (Table 5). The majority were part-timers, but a maximum of 180 full-timers were in post in $1944 .^{28}$ It was something of a disappointment that the number of full-time physicians in industry decreased substantially in the immediate post-war period, as though industrialists had quickly forgotten the benefits they had derived from them in more stringent times. In 1951, the Dale Committee found that there were only 51 full-time medical officers, although a further 339 were working between 3 and 12 hours a week in industry and 1,397 were working for 3 hours or less. ${ }^{29}$

28 Stewart, writing just after the war, gives the maximum number as 200 , but he is probably "rounding up". There were also many more nurses employed in industry-Stewart quotes the figure of 9,000 - and their role during the war would repay further study. D Stewart, 'Occupational health', in A
Massey (ed.), Modern trends in public health, London, Butterworth, 1949, pp. 386-418.

${ }^{29}$ Report of a committee of enquiry on industrial health services, London, HMSO, 1951, p. 29 (table B). 
Occupational Health during the Second World War

Table 4

Number of accidents reported to Factory Inspectorate, 1937-1946

$\begin{array}{lrlll}\text { Year } & \text { Fatal } & \text { Non-fatal } & \text { Total } & \text { Rate/10 } \\ 1937 & 1,003 & 191,536 & 192,539 & 30 \\ 1938 & 944 & 179,159 & 180,103 & 29 \\ 1939 & 1,104 & 192,371 & 193,475 & 28 \\ 1940 & 1,372 & 230,607 & 231,979 & 34 \\ 1941 & 1,646 & 269,652 & 271,298 & 38 \\ 1942 & 1,363 & 313,267 & 314,630 & 43 \\ 1943 & 1,220 & 309,924 & 311,144 & 42 \\ 1944 & 1,003 & 281,578 & 282,581 & 40 \\ 1945 & 851 & 239,802 & 240,653 & 37 \\ 1946 & 826 & 222,933 & 223,759 & 34\end{array}$

Data from Annual reports of Chief Inspector of Factories.

\section{Medical Supervision}

One particularly important aspect of occupational health during the war was the issue of the Factories (Medical and Welfare Services) Order, 1940, by the Ministry of Labour and National Service in an attempt to safeguard the health of those engaged in the arms production drive. The Order enabled the Chief Inspector to require the provision of medical, nursing and welfare services in essential works, including the medical supervision of employees. Medical supervision had already been required under regulations for workers exposed to a number of hazards including lead, TNT, $x$ irradiation, pitch and tar, nickel, and some intermediates used in the manufacture of synthetic dyes. The new order, however, widened the scope for supervision generally. The major impediment to implementing it was the shortage of trained doctors and nurses, but employers seem to have recognized the value of such medical and nursing personnel as were available and at least in the middle period of the war it had not been necessary for the inspectorate to direct any employer to appoint a doctor or a nurse. Indeed, the embryo industrial health service which was created appeared to be so successful that Merewether wrote in his 1942 report that it was inconceivable that it would be allowed to disappear when the war had ended. ${ }^{30}$

A number of government departments created their own occupational health services, foremost of which was the Royal Ordnance which had its own full-time medical service and was singled out for praise many times in the Annual Reports of the Chief Inspector of Factories. There were about forty ordnance factories around Manchester during the war and R S F Schilling, who was in the medical inspectorate at the start of the war, remembers the standard of care as being of a very high order. ${ }^{31}$

30 E R A Merewether, in Annual report of the Chief Inspector of Factories for the year 1942, London, HMSO, 1943, p. 39.

31 R S F Schilling, personal communication. 


\section{H A Waldron}

Table 5

Number of full-time and part-time medical officers in industry during the Second World War

$\begin{array}{rllr}\text { Year } & \text { Full-time } & \text { Part-time } & \text { Total } \\ 1941 & 150 & & \\ 1942 & 161 & 689 & 850 \\ 1943 & 174 & 744 & 918 \\ 1944 & 180 & 890 & 1,070 \\ 1945 & 143 & 903 & 1,046\end{array}$

Data from Annual reports of Chief Inspector of Factories.

\section{The Hope for the Future}

The contribution of industrial medicine in-at the very least-maintaining the standard of health of the working population under the most extreme conditions gave rise to what Merewether referred to as

a remarkable growth in health consciousness generally amongst the industrial population.... This, we hope, will lead ultimately to the development of an almost instinctive appreciation of occupational factors inimical to health and so to every worker contributing his personal effort to the attainment of Industrial Health. ${ }^{32}$

In April 1943, the Ministry of Labour convened a conference on industrial health at which the Minister, Ernest Bevin, ${ }^{33}$ said in his introduction:

The great strides in production which have been achieved in this struggle would never have been possible without all the efforts to improve safety, health and hygiene in the past year, ... what we have done during the war must be consolidated and developed after the war. ${ }^{34}$

It was in 1943 or thereabouts that serious consideration began to be given to the form which industrial health would take once the war was over. To some, including A W Garrett, the Chief Inspector of Factories, it seemed clear that workers who had had

32 E R A Merewether, 'The scope of industrial health' in Conference on industrial health, London, HMSO, 1943, p. 39.

33 Bevin had been interested in industrial health since his trade union days. In 1937, at a meeting arranged to discuss the new Factories Act, he looked forward to the formation of a co-ordinated medical service. "The bulk of medical practice is this country is concerned with industrial workers," he wrote, "How can this be linked with the industrial medical service we contemplate?" E Bevin, "The wider issue of health legislation in industry', Br. med. J., 1937, ii: 610-13. Bevin had been appointed a member of the Industrial Health Research Board in 1932 and he was a firm supporter of the Industrial Orthopaedic Society's Manor House Hospital ("Labour's Own Hospital") during his union days. (For further details see Cooter, op. cit., note 8 above, especially chs 7 and 10.) In 1937 Bevin established a joint committee of the General Council of the TUC and the BMA which discussed, inter alia, the rehabilitation of injured workers, a topic to which he made a great contribution when be became Minister of Labour. See A Bullock, The life and times of Ernest Bevin. Volume one. Trade union leader 1881-1940, London, Heinemann, 1960, pp. 602-3. One of his first acts as Minister of Labour was to get the administration of factory legislation and the Factory Inspectorate transferred to his ministry from the Home Office. See ibid., vol. 2, 1967, pp. 78-9. Lane (op. cit., note 5 above, p. 119) writes that as Minister of Labour, Bevin and his Permanent Secretary attended one of Lane's week-end training courses in industrial medicine in Manchester; this must have been the first, and the last, time such a thing happened.

${ }^{34}$ Bevin, in Conference on industrial health, op. cit., note 32 above, p. 1 . 
experience of conditions in the newer factories, "will not readily accept a return to the congested workrooms and poor standard of amenities which have been common in many of the older industries." 35 This thinking was no doubt encouraged by the Beveridge Report, published the previous year, in which reforms for the social and allied services had been suggested, and the contemporaneous discussion about reforms in the provision of general health services. In many minds it appeared that industrial medicine should be part of the general provision. At the Ministry of Labour Conference, the Minister of Health, Ernest Brown, stated:

... we can think of all ordinary medical advice . . . as being provided to all workers and their families in the home, or against the background of the home . . . a universal health service, may involve specialist medical advice and supervision in regard to special industrial conditions and environment. ${ }^{36}$

The Chief Medical Officer, Sir Wilson Jamieson endorsed this view, as did Charles Hill, then Chairman of the Central Council for Health Education. ${ }^{37}$

During the war years industrial health was seen to have an importance that it has probably not enjoyed since. An examination of the views expressed by those closely associated with either it or the government-the views of Merewether, Bevin, Brown, Jamieson and Hill have already been cited-leave little doubt that they expected that it would either be established as a national service in its own right after the war, or become part of the national health service in whatever form that was to assume. If there were dissenters from this view, they were not vociferous and did not appear in print. Rather, there was very great activity which could reasonably be construed as working towards this aim.

In 1940 the British Medical Association (BMA) had set up a committee to examine the role of industrial health. The committee considered that "medical supervision . . . should be an essential feature of every factory organization, whether large or small", 38 and discussed the various ways in which industrial health was to develop after the war. The members stressed that whatever form the service eventually took, it was important that it should be co-ordinated with other forms of health service and allow for continuing training for industrial medical officers and for systematic medical research in industry.

In his section in the Chief Inspector's 1944 report, Merewether described the various activities which were taking place throughout the country in preparation for developments after the war:

\footnotetext{
35 A W Garrett, in Annual report of the Chief Inspector of Factories for the year 1942, HMSO, London, 1944, p. 4.

36 Brown, in Conference on industrial health, op. cit., note 32 above, p. 8 .

37 Jamieson, at the Ministry of Labour Conference, said, "I look upon medical work within the factory as one of the specialities for which the general practitioner should be encouraged to prepare himself" (Conference on industrial health, op. cit., note 32 above, p. 25) while Hill was of the view that, "If it is a national obligation to see that the factory
}

\begin{abstract}
environment is as well cared for as the non-factory environment, this service should not be left as a purely employers' service. . . . I do not contemplate with equanimity the prospect of a comprehensive service being administered under the major Local Authorities ... whatever the set-up subsequently determined may be, my plea is that the factory health service should be an integral part of that service" (ibid., p. 45).

${ }^{38}$ Report of committee on industrial health in factories, London, British Medical Association, 1941 , p. 8.
\end{abstract}




\section{H A Waldron}

The increase in appreciation of the importance of Industrial Health is evident in many ways and is widespread [my italics]. The Royal College of Physicians has issued a valuable report on the subject, the TUC a statement and a resolution, the Universities of Durham, Glasgow and Manchester are in process of establishing Departments of Industrial Health with the assistance of substantial grants by the Nuffield foundation. . . . The Society of Apothecaries is taking steps to institute a Diploma in Industrial health. The MRC has set up a Research Unit at Cardiff to study pneumoconiosis in coal miners ... The MRC's Department of Industrial Health Research at the London Hospital is actively prosecuting research.

The Universities of Bristol, Leeds, Sheffield and Manchester, with the London School of Hygiene and the Birmingham Accident Hospital provide brief courses . . . in Industrial Health ...

It is my belief that ... the healthiness or otherwise of an occupation will become increasingly the dominant factor in the choice of an occupation. Inescapably, therefore, unhealthy occupations must be made healthy or they will languish and ultimately fade out from lack of labour. ${ }^{39}$

The report published by the Royal College of Physicians to which Merewether referred was an interim report of the Social and Preventive Medicine Committee under the chairmanship of the President, Lord Moran. ${ }^{40}$ The committee urged in the most unequivocal terms that "an Industrial Health Service should be planned in.a bold manner without much regard for traditional arrangements". It was to be national in scope and apply to everyone, no matter what their occupation. The committee further recommended that clinical facilities, including beds for consultants, should be provided and that the service should be an essential part of the national health service with responsibility to the Chief Medical Officer of the Ministry of Health who would be, ex officio, Chief Medical Officer of the Industrial Health Service. Moran had previously somewhat pre-empted the findings of his committee by stating elsewhere that "the structure of industrial medicine will be the general structure of the medical services of the country, working on parallel lines", ${ }^{41}$ so there is no doubting his enthusiasm for the project.

\section{The British Journal of Industrial Medicine}

Another way in which the general enthusiasm for industrial health manifested itself was through the decision to publish a new journal, the British Journal of Industrial Medicine. The impetus for this had been provided by the Association of Industrial Medical Officers (AIMO) at the end of 1942. The matter was raised with the BMA who were then already publishing three other quarterly specialist journals, the Journal of Neurology, Neurosurgery and Psychiatry, Archives of Disease in Childhood and the British Heart Journal. Initially there was some disagreement amongst the interested parties as to the style of the proposed journal. The view of the AIMO was that it should be their official publication but Hugh Clegg, deputy editor of the British Medical Journal and its acting editor because Leonard Horner was ill, strongly urged that it should be similar in style and content to the three other specialist journals published by the BMA. In the end his view prevailed. The formal decision to publish the journal was taken at the meeting of the

39 E R A Merewether, in Annual report of the Chief Inspector of Factories for the year 1944, London, HMSO, 1945, pp. 45-6.

40 Royal College of Physicians, Social and Preventive Medicine Committee, Industrial health, second interim report, London, Royal College of Physicians, 1945.

41 Lord Moran, 'Foreword', Br. J. ind. Med., 1944, 1: no page number. 
journal committee of the BMA on 13 January 1943 and the first issue appeared in January 1944. It had been planned at first that Sir Henry Bashford, chief medical officer to the Post Office, would be the editor-in-chief but when he was appointed as Medical Adviser to the Treasury in 1943 he declared to the editorial committee that he felt unable to continue to act and Donald Hunter was appointed in his stead. ${ }^{42}$ Hunter was a general physician at the London Hospital who had become interested in occupational medicine from seeing patients with industrial diseases in his clinics. He was director of the MRC Department for Research in Industrial Medicine which had been established at the London Hospital in 1943, and he and his colleagues contributed many of the early papers to the new journal. A small allocation of paper was made for the first issue, which rapidly went out of print. A reprint was made with a new allocation of paper but supply was still not able to keep up with demand. There was no immediate shortage of copy for, despite Clegg's intentions, the first two volumes contained general articles-"potboilers" as they were described by one of the later editors. ${ }^{43}$ The later contributions made by Hunter and his colleagues, most notably Kenneth Perry, however, undoubtedly helped to raise the standard and the standing of the journal.

\section{Post-War Industrial Medicine. Hope Deferred or Hope Abandoned?}

The hopes that industrial medicine would be incorporated into the National Health Service were dashed by the appearance of the White Paper, A National Health Service, in which it was made clear that industrial health was not to be part of a comprehensive service. ${ }^{44}$ Discussing what was mean by "comprehensive" in terms of the new proposals the document said

This term does not mean that there should be no other Government or private activity involving the use of a medical expert, or having any bearing on health ... the present system of factory medical inspection and the arrangements made for the employment by industry of "works doctors" are cases in point.

And, in defining the role of the works doctor, the document continued:

The 'works doctors' do not, any more than the Factory Inspectorate, exist primarily as a personal medical function; but in connection with their functions of advising management and dealing with preventive and first-aid measures they often provide, incidentally and as a matter of common-sense utility, a certain amount of useful personal medical advice to the factory employees on the spot.

It might be thought that doctors in industry-like many of the private consultantswould have had objections to becoming part of a national service but this was apparently not so. An editorial in the BJIM viewed the exclusion of industrial health from the White Paper as a matter of regret ${ }^{45}$ and the AIMO, at its annual general meeting of 14 October 1944 , found itself unable to subscribe to the separation of industrial health from a national

\footnotetext{
42 These details are taken from the Minute Book of the British Journal of Industrial Medicine. The earliest minutes are unfortunately incomplete and give only a minimum of information about this interesting period in the journal's history.
}

\footnotetext{
43 R Schilling, 'Donald Hunter 1898-1978. Editor BJIM 1944-50', Br. J. ind. Med., 1993, 50: 5-6.

44 Cmnd 6502, 1944.

45 Editorial, 'A new outlook', Br. J. ind. Med., 1944, 1: 197-8.
} 


\section{H A Waldron}

health service. ${ }^{46}$ The post-war Labour Government ameliorated the position somewhat by requiring the nationalized industries to include medical services. ${ }^{47}$ Thus, for example, the National Coal Board was established with a full-time industrial health service which was directed by a Chief Medical Officer who was assisted by a staff of 65 medical officers and 300 nurses; they met the needs of the 700,000 miners employed by the NCB throughout the country. ${ }^{48}$ This step, however, was a far cry from the aspirations of those who had been advocating industrial health for all during the war years.

It is difficult to know exactly why it was decided not to incorporate industrial medicine into the NHS despite the strength of the support for such a move. The most likely explanation is that Bevin was determined not to let industrial health pass out of the purview of his Ministry of Labour. Phillips, who has examined this area in some detail, is in no doubt that Bevin was culpable and that the device he used to get industrial medicine excluded was to stress that it was a preventive and not a personal medical service. ${ }^{49}$ There is good circumstantial evidence to support the view that Bevin was indeed responsible. He did not like the Beveridge report, referring to it at a meeting of the Scottish TUC in April 1943 as a "social ambulance scheme". 50 And it is noteworthy that one of his first acts as Minister of Labour was to take the Factory Department from the Home Office into his own ministry and he felt strongly that this was where it should always stay. According to Bullock, Bevin had made his mind up that the administration of the Factories Acts should not return to the Home Office and he was equally determined to keep factory medical services out of the hands of the Minister of Health and link them instead with the medical branch of the Factory Inspectorate. ${ }^{51}$ Watkins, by contrast, considered that it was Bevan rather than Bevin who was to blame. His view was that Bevan saw the NHS as a means of paying doctors' bills and not as a means of pursuing health as a social goal; the NHS was rooted in poverty and provided a mechanism whereby the poor could pay their doctor. Thus it had nothing to do with preventive medicine and since-as the White Paper made clear-industrial health was not a personal health service, it could not form part of the NHS. ${ }^{52}$

In any event, the post-war years seem to have been characterized by inactivity through committee. The Attlee government set up the Dale Committee to enquire into industrial health services. They reported in 1951, stating that their enquiry "has left us with no doubt as to the essential importance of industrial health services from whatever angle the subject is considered" 53 and recommending that "there should eventually be some comprehensive

\footnotetext{
46 'Proceedings of the Association of Industrial Medical Officers', Br. J. ind. Med., 1945, 2: 63.

47 It was somewhat ironic that the National Health Service itself was not required to have an occupational health service for its employees when it was set up. Not until 1968, when the Tunbridge Committee reported, was any attempt made to establish occupational health services within the NHS and these were-and still are-piecemeal, at best. Report of the joint committee on the care of the health of hospital staff, London, HMSO, 1968.

48 A Meiklejohn, 'Sixty years of industrial medicine in Great Britain', Br. J. ind. Med., 1956, 13: $155-62$.
}

\footnotetext{
49 M R Phillips, 'Government policy and the development of occupational health services since 1939', MMSc thesis, University of Nottingham, 1976.

50 Bullock, op. cit., note 33 above, vol. 2, p. 64.

51 Ibid., p. 79.

52 S J Watkins, 'Occupational health services-part of the health care system?' MSc thesis, University of Manchester, 1982.

${ }^{53}$ Report of a committee of enquiry on industrial health services, Cmnd 8170, London, HMSO, 1951, p. 14.
} 


\section{Occupational Health during the Second World War}

provision for occupational health covering not only industrial establishments of all kinds, both large and small, but also . . . non-industrial occupations." 54 No action was taken to implement this or any other of their recommendations. ${ }^{55}$

In 1962, the Porritt Committee recommended the extension of occupational health services and suggested that the work of the Factory Medical Inspectorate could, with advantage, be transferred to the Ministry of Health. ${ }^{56}$ Again, no action relating to occupational health services followed the publication of this report. By this time, however, it is probable that such a move no longer enjoyed any support from occupational physicians perhaps fearing for their own positions. Sharp Grant, writing shortly before the Porritt Committee published, commented on the relationships between occupational health services and the NHS and the public health service in particular. He was against any closer links with public health services, noting that to be effective, occupational medicine should be allowed a "reasonable measure of independence"; if it were to become a national service, then he felt that it should be under the auspices of the Ministry of Labour and National Service. ${ }^{57}$

The Appointed Factory Doctor Service (AFDS) was examined by another body, this time a sub-committee of the Industrial Health Advisory Committee, which recommended that a more expert service should be established to replace the existing AFDS. ${ }^{58}$ No changes followed this report until six years later in 1972 the Employment Medical Advisory Service Act was passed and the Medical Branch of the Factory Inspectorate was replaced by the Employment Medical Advisory Service (EMAS) although it remained within the Ministry of Labour. EMAS was very much the brain child of Trevor Lloyd Davies, who was the last Chief Medical Inspector, and whose ambition it was that it would "provide for the first time in Britain a national focus for the development of occupational medicine". 59 It was planned that when fully operational, the service would employ 120 doctors, approximately two-thirds of them full-time, who would be supported by nurses and others, but this target has rarely been achieved.

Occupational medicine received scant attention from the Royal Commission on Medical Education although, in its report, the commission noted that the Confederation of British Industry had expressed an urgent need for more widespread development of health services in industry. The commission considered that the reason occupational health had not expanded was that priority had been given to the provision of a comprehensive system of medical services and its members saw no prospect that this situation would change in the immediate future, ${ }^{60}$ and there they were certainly right.

\footnotetext{
54 Ibid., p. 19.

55 Support for incorporating industrial medicine into the NHS had also come from the Conservative Party. McLeod and Maude had written that "There may be a strong case for incorporating Industrial Medical Services [into the NHS] as soon as possible. The standard of treatment and the equipment vary tremendously, and central responsibility would be an advantage." I McLeod and A Maude, One nationthe Tory approach to social problems, Tory Central Office, 1950. This was not a view which has found much sympathy with any subsequent Conservative administration.

${ }^{56} \mathrm{~A}$ review of the medical services in Great
}

\author{
Britain, London, Medical Services Review \\ Committee, 1962, pp. 138-9. \\ $57 \mathrm{~J}$ Sharp Grant, 'The development of occupational \\ medicine', J. Publ. Health, 1959, 22: 47-57. \\ 58 The Appointed Factory Doctor Service, London, \\ HMSO, 1966. \\ 59 T A Lloyd Davies, 'Employment Medical \\ Advisory Service', Health Trends, 1973, 5: 45-7. For \\ an account of the events leading up to the formation \\ of EMAS see, M Gracey, 'Employment Medical \\ Advisory Service', Br. J. ind. Med., 1973, 30: 92-4. \\ ${ }^{60}$ Report of the Royal Commission on medical \\ education 1965-68, Cmnd 3569, London, HMSO, \\ 1968, p. 29.
}




\section{H A Waldron}

Throughout this period, the need for some form of comprehensive occupational health service was recognized by the various committees which had met to consider the matter, but there was now no consensus on the form it should take or the means by which it could be achieved and the successive reports seem to have become increasingly less optimistic that any change in the status quo would ever actually come about.

The Robens Committee, which reported in 1974, was considerably less enthusiastic than previous committees about the need for medical services in industry and not at all in favour of a comprehensive service. They noted earlier recommendations for a comprehensive service but stated that "it is not always easy to see exactly what is meant by this", 61 a surprising observation since their predecessors had found no difficulty whatsoever in knowing and describing what they meant. Furthermore, the Robens Committee suggested that the provision of an occupational health service "does not imply a need to have a doctor at every sizeable factory". 22 The report of this committee finally did away with both the notion and the possibility of a comprehensive occupational health service, which they considered the country could not afford. Instead, they advocated that "the traditional distinction . . . between general health and 'diseases of occupation' is a useful one and needs to be preserved if decisions as to what is necessary in the future in the field of occupational medicine are not to become confused". 63 They chose instead, to rely on the extension of the EMAS to meet the nation's needs in occupational medicine. The recommendations of the Robens Committee were later to be embodied in the Health and Safety at Work, etc., Act (1974). Whatever benefits may have been derived from this piece of legislation, the provision of an occupational health service adequate for the needs of the entire working population was certainly not one of them, and the degree to which the reliance on EMAS has been a success must be left to others to debate.

\section{Conclusions}

It took two world wars to demonstrate how valuable a comprehensive occupational health service can be to an industrial nation, but perhaps it is a service that can be afforded only in wartime. Certainly, the enthusiasm and the prospects for occupational health were never greater or stronger than during the Second World War. The number of doctors in industry declined considerably afterwards and the need for occupational health to become part of the national health service was lost sight of. Although lip service was given to the notion of a comprehensive service by many committees who considered the matter after the war, no government took any substantive steps to set one up and by the time the Robens Committee reported it was clear that the will to do so had gone. It was too expensive to contemplate and continues to be so. The answer to the question posed in the title of this paper must be that hope has been abandoned and surely, those "happy highways" cannot come again. ${ }^{64}$

61 Safety and health at work. Volume 1. Report of the Committee 1970-72, Cmmd 5034, London, HMSO, 1972, p. 118.

62 Ibid., p. 121.

63 Ibid, p 122.

\footnotetext{
64 Quoted from A E Housman's Shropshire lad: "That is the land of lost content/I see it shining plain, $/$ The happy highways where I went/And cannot come again".
} 